\title{
Immunoglobulin Light Chain Variable Region Gene Sequences for Human Antibodies to Haemophilus influenzae Type b Capsular Polysaccharide Are Dominated by a Limited Number of $V_{\kappa}$ and $V_{\lambda}$ Segments and VJ Combinations
}

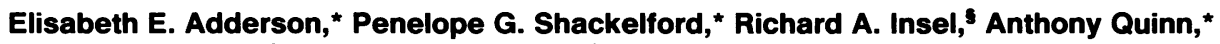 \\ Patricia M. Wilson, ${ }^{\star}$ and William L. Carroll ${ }^{\star}$ \\ ${ }^{*}$ Division of Infectious Diseases and ${ }^{\ddagger}$ Hematology Oncology, Mallinckrodt Department of Pediatrics, Washington University School of \\ Medicine, St. Louis Children's Hospital, St. Louis, Missouri 63110; and ${ }^{\S}$ Department of Pediatrics, University of Rochester School of \\ Medicine and Dentistry, Rochester, New York 14642
}

\begin{abstract}
The immune repertoire to Haemophilus influenzae type b capsular polysaccharide (Hib PS) appears to be dominated by certain light chain variable region genes $\left(\operatorname{IgV}_{L}\right)$. In order to examine the molecular basis underlying light chain bias, $\operatorname{IgV}_{L}$ genes have been cloned from a panel of heterohybridomas secreting human anti-Hib PS (antibody) (anti-Hib PS Ab). One hybridoma, representative of the predominant serum clonotype of anti-Hib PS Ab in older children and adults following immunization or Hib infection, uses a $V_{k} I I$ segment identical to the germline gene A2, and a JK3 segment. A second kappa hybridoma uses a member of the $V_{\alpha} I$ family and a JK4 segment. Four lambda antibodies, all cross-reactive with the structurally related antigen Escherichia coli $\mathrm{K} 100 \mathrm{PS}$, use $\mathrm{V}_{\lambda}$ VII segments which are $96-98 \%$ homologous to one another, and may originate from a single germline gene. Two additional lambda antibodies, not K100-cross-reactive, are encoded by members of the $V_{\lambda}$ II family. All lambda antibodies use highly homologous $J_{\lambda} 2$ or $J_{\lambda} 3$ segments. The $V J$ joints of all lambda antibodies and the $V_{\kappa}$ II-encoded antibody are notable for the presence of an arginine codon, suggesting an important role in antigen binding. Although more complex than heavy chain variable region gene usage, a significant portion of serum anti-Hib PS Ab is likely to be encoded by a limited number of $V_{k}$ and $V_{\lambda}$ segments and VJ combinations, which may be selectively expressed during development, or following antigen exposure. (J. Clin. Invest. 1992: 89:729-738.) Key words: B-cell repertoire • somatic mutation • gene rearrangement $\bullet$ carbohydrate antigen
\end{abstract}

\section{Introduction}

The development of the antibody repertoire involves the recombination of individual members of two or three groups of germline segments, nucleotide insertion or deletion at these junctions, and somatic mutation of rearranged genes (1-4). The individual contributions of these molecular mechanisms

Presented in part at the annual meeting of the Society for Pediatric Research, New Orleans, LA, 2 May 1991, and published in abstract form (Pediatr. Res. 29:155A).

Address correspondence and reprint requests to Dr. William $\mathbf{L}$. Carroll, Program in Human Molecular Biology and Genetics, University of Utah, Bldg. 533, Salt Lake City, UT 84112.

Received for publication 14 August 1991 and in revised form 5 November 1991 .

J. Clin. Invest.

(c) The American Society for Clinical Investigation, Inc.

$0021-9738 / 92 / 03 / 0729 / 10 \quad \$ 2.00$

Volume 89, March 1992, 729-738 to the generation of the immune repertoire against a specific antigen has been extensively studied in murine systems, but it is uncertain whether these findings can be extrapolated to humans. The chromosomal organization of the human heavy and light chain variable region segments within the immunoglobulin loci differ from those of mice (5-7). Furthermore, the response of highly inbred laboratory animal strains, and the use of simple haptens in most studies, may not be comparable with the human response to clinically relevant antigens, such as those presented by microbial pathogens.

The immune response to Haemophilus influenzae type b capsular polysaccharide (Hib PS) ${ }^{1}$ is an excellent model to examine the immune repertoire to a functionally significant antigen. Hib is a major bacterial pathogen in young children and antibody directed against the capsular polysaccharide, a repetitive polymer of polyribosylribitol phosphate, protects against invasive infection (8). Similar to the response to other polysaccharide antigens, the immune response to Hib PS is age-dependent. Children under 5 yr have lower antibody responses and are at greatest risk of infection. Additionally, there appear to be variations in individual and ethnic susceptibilities to invasive Hib disease (9-11). Analysis of the immune response to Hib PS will contribute to our understanding of the development of the human antibody repertoire, and provide insight into age-related and possible genetic predisposition to infection caused by Hib.

Previous studies employing partial amino acid sequencing of anti-Hib PS serum antibody purified to clonality have shown that light chains of anti-Hib PS antibody are encoded by $V_{\lambda}$, and at least three $V_{\kappa}$ gene families (12). Although highly informative, these studies have inherent technologic limitations. To obtain sufficient antibody for analysis, only individuals with antibody concentrations much higher than those elicited in young infants could be studied (12). Amino acid sequences were unobtainable on $\mathrm{V}_{\lambda}$-encoded antibodies, and certain regions of $\mathrm{V}_{\alpha}$-encoded antibodies $(12,13)$. Obtaining nucleic acid sequences of variable region genes encoding antiHib PS Abs would permit precise comparison of variable region genes obtained from different individuals, allowing classification of these genes into germline families and subfamilies, analysis of D- and J-segment usage, and assessment of the role of somatic mutation in the clonal evolution of this immune response. Additionally, this information could be applied to examination of the germline and expressed immune repertoire

1. Abbreviations used in this paper: Ars, anti-p-azophenylarsonate; Hib, Haemophilus influenzae type b; Hib PS, Hib capsular polysaccharide; $\mathrm{IgV}_{\mathrm{L}}$, light chain variable region gene; PCR, polymerase chain reaction; SSC, standard saline citrate. 
of individuals of various ages, and populations at high risk for invasive Hib infection.

Our previous work, and that of others, indicated that the heavy chains of anti-Hib PS Abs are encoded by a very restricted number of $\mathrm{V}_{\mathrm{H}} \mathrm{III}$ gene segments, in combination with a variety of $D$ and $J_{H}$ segments $(12,14)$. We have extended our studies to examine light chain variable region gene $\left(\mathrm{IgV}_{\mathrm{L}}\right)$ usage in the human anti-Hib PS response. A major component of serum anti-Hib PS Ab expresses a cross-reactive idiotype associated with the use of a $\mathrm{V}_{\kappa} \mathrm{II}$ gene $(15,16)$. Antibodies expressing this light chain account for the majority of anti-Hib PS antibody in older infants and adults following invasive Hib disease or immunization. Most lambda-encoded anti-Hib antibodies and some kappa-encoded ( $\mathrm{V}_{k} \mathrm{I}$ and $\left.\mathrm{V}_{\mathrm{k}} \mathrm{III}\right)$ anti-Hib PS Abs cross-react with the capsular polysaccharide of $E$. coli $\mathrm{K} 100(12,17)$. Naturally acquired antibody of the majority of children expresses K100 PS cross-reactivity, and thus, colonization with this organism may provide protective immunity before exposure to $\mathrm{Hib}(18)$. Our results indicate that two important anti-Hib PS light chains, one associated with $\mathrm{V}_{\kappa} \mathrm{II}$ expression and the other with lambda antibodies cross-reactive with K100 PS, are encoded by two germline elements that may be expressed with little or no somatic mutation. Moreover, a nongermline-encoded arginine at the $\mathrm{VJ}$ joint is seen in the majority of anti-Hib PS Ab light chains, a result suggesting an essential role in antigen recognition.

\section{Methods}

Hybridomas. Heterohybridomas secreting human monoclonal antiHib PS antibody were obtained, as previously described (14). Volunteers were immunized with either plain Hib-PS vaccine (Praxis Biologicals, Rochester, NY) or Hib-PS diphtheria toxoid conjugate vaccine (Hib-PS-D) (Connaught Laboratories, Swiftwater, PA). $7 \mathrm{~d}$ following immunization, peripheral blood lymphocytes were harvested and fused to the nonsecreting mouse myeloma SP2/O-Ag14. Anti-Hib PS Ab was detected by binding to Hib PS in an ELISA, as previously described (14). Specificity was documented by antibody binding to ${ }^{125} \mathrm{I}$-labeled antigen (19), and by inhibition of binding by $1.25 \mu \mathrm{g} / \mathrm{ml}$ of soluble Hib PS in an ELISA (20). Cross-reactivity with E. coli K100 PS was assayed by inhibition of binding to Hib PS-poly-L-lysine with 100 $\mu \mathrm{g} / \mathrm{ml}$ of soluble $\mathrm{K} 100 \mathrm{PS}$ in an ELISA. An antibody concentration was selected that gave half-maximum absorbance in the ELISA. Greater than $15 \%$ inhibition was considered positive. The $E$. coli K100 PS was prepared from $E$. coli strain Easter, by the same method used to prepare Hib PS (19). The generation of hybridoma line 16M3C8 was described previously (21).

Cloning and sequencing of $I g V_{L}$ genes. Total RNA was prepared from $10^{6}$ hybridoma cells using the guanidine isothiocyanate method (22). 2 to $8 \mu \mathrm{g}$ of total RNA served as template for first-strand cDNA synthesis, as previously described (14). 10 pmol of a consensus antisense primer corresponding to conserved sequences within the human kappa or lambda constant region $(23)\left(C_{k}\right.$ codons 181172:5'CAGCGTCAAGCTTCTGCTGTGGCTGTAGGT 3', $\mathrm{C}_{\lambda}$ codons 171-181:5'CAGGCTCAGGAAGCTTCTGGCCGCGTACTTGTT $3^{\prime}$ ) was used to initiate cDNA synthesis by avian myeloblastosis virus (AMV) reverse transcriptase (RT; Life Sciences, St. Petersburg, $\mathrm{FL})$. One half $(10 \mu \mathrm{l})$ of the cDNA reaction was directly diluted into polymerase chain reactions (PCR), (24).

PCR conditions were as previously described, except that $70 \mathrm{pmol}$ of an internal constant region consensus primer $\left(C_{k}\right.$ codons 125 117:5'CAACGGATCCTCTGATGGCGGGAAGAT 3 ', $\mathrm{C}_{\lambda}$ codons 125-117:5'TGGGGATCCAGCTCCTCAGAGGAGGG $3^{\prime}$ ) and 70 pmol of a degenerate $3^{\prime}$ kappa or lambda leader sequence primer (kappa:5'GGGAATTCATGGACATG(GA)(GA)(GA)(GAT)(TC)CC-
(ACT)(GAC)G(TC)(GT)CA(GC)CTT 3', lambda 5'GGGAATTCATG(GA)CCTG(GC)(AT)C(TC)CCTCTC(TC)T(TC)CT(GC)(AT)(TC)C 3 ) were used to amplify rearranged variable region genes $(14,25)$.

PCR products were isolated from low melting-point agarose gels (FMC Bioproducts, Rockland, ME). Artificial restriction enzymes sites in each primer allowed directional cloning into M13mp18 and M13mp19 phage vectors (Boehringer Mannheim Corp., Indianapolis, IN). Sequencing of $V_{L}$ genes was performed by the dideoxy technique (26). Two to five positive clones were obtained and sequenced for each hybridoma gene.

The $16 \mathrm{M} 3 \mathrm{C} 8$ light chain was generated by amplification of firststrand CDNA, with primers corresponding to amino acid positions -7 of the leader, to position 6 of the lambda light chain (5'CTGCACAGGGTCCTGGGCCGAGCTCGTGGTGACTCA 3'), and the $\mathrm{C}_{\lambda}$ constant region (antisense, 5'GCATTCTAGACTATTATGAACATTCTGTAGGGGC $3^{\prime}$ ). Blunt-ended PCR products were cloned into SmaI cut M13 mp18 and M13mp19 and sequencing was also performed by the dideoxy method.

Southern blot analysis of genomic DNA. Peripheral blood was obtained from 10 unrelated healthy adult volunteers, from L.S. (the donor of hybridoma LSF2), and from a parent of L.S. Lymphocytes were separated on a Ficoll-Hypaque gradient, and genomic DNA was prepared by Proteinase K digestion (27). $10 \mu \mathrm{g}$ of each subject's genomic DNA was digested with BamHI (4 U/ $\mu \mathrm{g}$ DNA) (Boehringer Mannheim Corp.) at $37^{\circ} \mathrm{C}$ for $16 \mathrm{~h}$, according to manufacturer's specifications. Digested DNA was separated by electrophoresis in a $0.8 \%$ agarose gel using TAE buffer ( $0.04 \mathrm{M}$ Tris-acetate/0.001 M EDTA), and was transferred to Duralon UV membranes (Stratagene Inc., La Jolla, CA), using a positive pressure blotting apparatus (Posiblotter; Stratagene, Inc.). To examine germline representation of anti-Hib PS Ig genes, genomic DNA was hybridized with a 320-bp EcoRI/SmaI $V_{\lambda}$ segment from hybridoma LSF2 that lacked the associated $J_{\lambda}$ and $C_{\lambda}$ regions. Probe was radiolabeled to high specific activity using T7 DNA polymerase (28). Prehybridization and hybridizations were carried out in $5 \times$ standard saline citrate (SSC), $5 \times$ Denhardt's solution, and $200 \mu \mathrm{g} / \mathrm{ml}$ sheared and denatured salmon sperm DNA (Boehringer Mannheim Corp.) at $42^{\circ} \mathrm{C}$ overnight. Filters were washed with $2 \times$ SSC, $0.2 \%$ SDS at room temperature twice, then with $0.2 \times \mathrm{SSC}, 0.2 \%$ SDS at 55 to $60^{\circ} \mathrm{C}$ twice, and exposed to X-OMAT AR film (Eastman Kodak Co., Rochester, NY) for 2-7 d.

In order to further localize germline candidates within $\mathrm{V}$ region families, an oligonucleotide probe corresponding to conserved sequences within the CDR-1 region (sense oligonucleotide: 5'GGCTCCAGCACTGGAGATGTCACCAGT 3', antisense oligonucleotide: 5'GTAGGGATAATGACCACTGGTGACATCTCC 3) was hybridized to genomic DNA using the method described by Hellman (29). 15 $\mu \mathrm{g}$ of BamHI-digested human genomic DNA was separated by electrophoresis in $0.8 \%$ agarose gel using TBE buffer $(0.09 \mathrm{M}$ Tris-borate/ $0.002 \mathrm{M}$ EDTA). Agarose gels were dried under vacuum and hybridized in $5 \times$ saline/sodium phosphate/EDTA (SSPE), $0.1 \%$ SDS, and $10^{6}$ $\mu \mathrm{g} / \mathrm{ml}$ of sheared and denatured salmon sperm DNA with $2 \times 10^{6} \mathrm{cpm}$ of probe/ml of hybridization solution at $60^{\circ} \mathrm{C}$ for $16 \mathrm{~h}(30,31)$. Hybridization conditions were previously adjusted to minimize nonspecific binding. Gels were washed with $6 \times$ SSC at room temperature for 20 min twice, followed by a 4-h room temperature wash. The gel was finally washed in $6 \times \mathrm{SSC}$ for $3 \mathrm{~min}$ at $64^{\circ} \mathrm{C}$, and exposed to X-OMAT AR film for $4 \mathrm{~d}$.

\section{Results}

\section{Hybridomas}

Eight hybridoma cell lines from seven individuals were initially selected from 20 cell lines. All individuals demonstrated substantial increases in serum anti-Hib PS Ab 1 mo after vaccination (Table I). Hybridomas were selected to exemplify serologic characteristics (kappa or lambda expression, and K100 PS 
Table I. Summary of Hybridoma Cell Lines*

\begin{tabular}{|c|c|c|c|c|c|c|c|c|}
\hline \multirow[b]{3}{*}{ Hybridoma } & \multirow[b]{3}{*}{ Isotype } & \multirow[b]{3}{*}{ Age } & \multirow{3}{*}{$\begin{array}{l}\text { Vaccine } \\
\text { Form }\end{array}$} & \multirow{3}{*}{$\begin{array}{l}\text { K100 Inh } \\
\text { of } \mathrm{mAb}\end{array}$} & \multicolumn{4}{|c|}{ Serum Anti-Hib PS Ab } \\
\hline & & & & & \multicolumn{2}{|c|}{ Total Ab } & \multicolumn{2}{|c|}{$\lambda \mathrm{K} 100 \mathrm{Inh}$} \\
\hline & & & & & Pre & Post & Pre & Post \\
\hline $\mathrm{RC} 3$ & $\operatorname{Ig} A / \mathbf{k}$ & Adult & PS-D & - & 1.1 & 300 & 11 & 11 \\
\hline ED6.1 & $\mathrm{IgG}_{2} / \mathrm{k}$ & $4 \mathrm{yr}$ & PS-D & - & 0.8 & 22 & 0 & 0 \\
\hline SB5/D6 & $\operatorname{IgA}_{1} / \lambda$ & Adult & PS-D & + & 2.0 & 688 & 30 & 27 \\
\hline RAY4 & $\operatorname{Ig} A_{2} / \lambda$ & Adult & PS-D & + & 1.9 & 28 & 0 & 42 \\
\hline LSF2 & $\operatorname{IgA} A_{1} / \lambda$ & Adult & PS & + & ND & 138 & ND & 29 \\
\hline JB32 & $\operatorname{Ig} A_{1} / \lambda$ & $11 \mathrm{yr}$ & PS & + & 0.3 & 125 & 19 & 33 \\
\hline JB21 & $\mathrm{IgG}_{2} / \lambda$ & $11 \mathrm{yr}$ & PS & - & 0.3 & 125 & 19 & 33 \\
\hline $16 \mathrm{M} 3 \mathrm{C} 8$ & $\mathrm{IgG}_{2} / \lambda$ & Adult $^{\ddagger}$ & PS & - & ND & ND & ND & 0 \\
\hline
\end{tabular}

* Columns show name of hybridoma cell line, isotype of anti-Hib PS Ab secreted, age of subject at immunization, type of vaccine (PS is plain polysaccharide, PS-D is Hib PS covalently linked to diphtheria toxoid), presence $(+)$ or absence $(-)$ of inhibition of binding of antiHib PS Ab by E. coli K100 PS, concentration of total serum anti-Hib $\mathrm{PS} A \mathrm{AB}$ pre- and $1 \mathrm{mo}$ post-immunization, and percent inhibition of binding of serum lambda antibodies to Hib PS by E. coli K100 PS in pre- and 1 mo post-immunization sera. ${ }^{\ddagger}$ Pool of 3 adult donors. ND, not done.

cross-reactivity) and to represent the response to "T-independent" plain polysaccharide, or "T-dependent" polysaccharideprotein conjugate forms of antigen. (Table I).

Four lambda-expressing anti-Hib PS Ab, obtained from four different subjects, cross-reacted with K100 PS. One of these individuals, RAY4, had no detectable serum cross-reactivity before immunization. The Abs JB32 and JB21 were obtained from the same individual, and differed in heavy chain isotype and $\mathrm{K} 100$ cross-reactivity.
$\operatorname{Ig} V_{L}$ genes. $\operatorname{IgV}_{\mathrm{L}}$ nucleic acid sequences were obtained from two kappa and six lambda hybridomas. Candidate germline $\mathrm{IgV}_{\mathrm{L}}$ sequences were sought by comparing hybridoma sequences to those registered with EMBL and GenBank (32).

Four lambda-expressing hybridomas, derived from four unrelated subjects, use $V_{\lambda}$ segments which are $96-98 \%$ homologous to one another, and are members of the germline $V_{\lambda} \mathrm{VII}$ family of which a single member, $4 \mathrm{~A}$, has been previously described (33) (Fig. 1). Notably, each of these four $\mathrm{V}_{\lambda} \mathrm{VII}$-encoded hybridomas cross-reacts with K100 PS. The high degree of homology between these segments suggests that these genes may be encoded by a single, or group of, closely related germline elements. The four hybridoma genes share a number of nucleic acid differences (maximum nucleic acid sequence homology $89 \%$ ) from the only previously sequenced $\mathrm{V}_{\lambda} \mathrm{VII}$ germline gene $4 \mathrm{~A}$, implying that these genes may be derived from another, as yet undescribed, $\mathrm{V}_{\lambda}$ VII germline element.

The homology of the translated amino acid sequences of these $4 \mathrm{~V}_{\lambda} \mathrm{VII}$ sequences parallels the nucleic acid homology. The hybridoma $\mathrm{V}_{\lambda}$ VII genes are 90 to $97 \%$ homologous at the amino acid level (Fig. 2). Framework regions are 94 to $100 \%$ homologous, whereas CDR regions are 72 to $96 \%$ homologous. Whether these minor differences reflect genetic polymorphisms, or somatic mutation, cannot be resolved from these data.

JB21 and $16 \mathrm{M} 3 \mathrm{C} 8$, the lambda-expressing hybridomas which do not cross-react with $\mathrm{K} 100 \mathrm{PS}$, are encoded by a $\mathrm{V}_{\lambda} \mathrm{II}$ gene family member (34), (Fig. 3). JB21 is $91 \%$ homologous to the germline $V_{\lambda} 2.1$ gene (99\% homologous in framework regions and $74 \%$ homologous in CDRs). $16 \mathrm{M} 3 \mathrm{C} 8$ is $89 \%$ homologous to $\mathrm{V}_{\lambda} 2.1$ (95\% in framework regions and $77 \%$ in CDRs). JB21 shares $87 \%$ amino acid homology with the translated $\mathrm{V}_{\lambda} 2.1$ germline sequence $(99 \%$ in framework regions and $60 \%$ in CDR regions), and $16 \mathrm{M} 3 \mathrm{C} 8$ shares $82 \%$ amino acid homology (92\% in framework regions and $60 \%$ in CDRs) (Fig. 4).
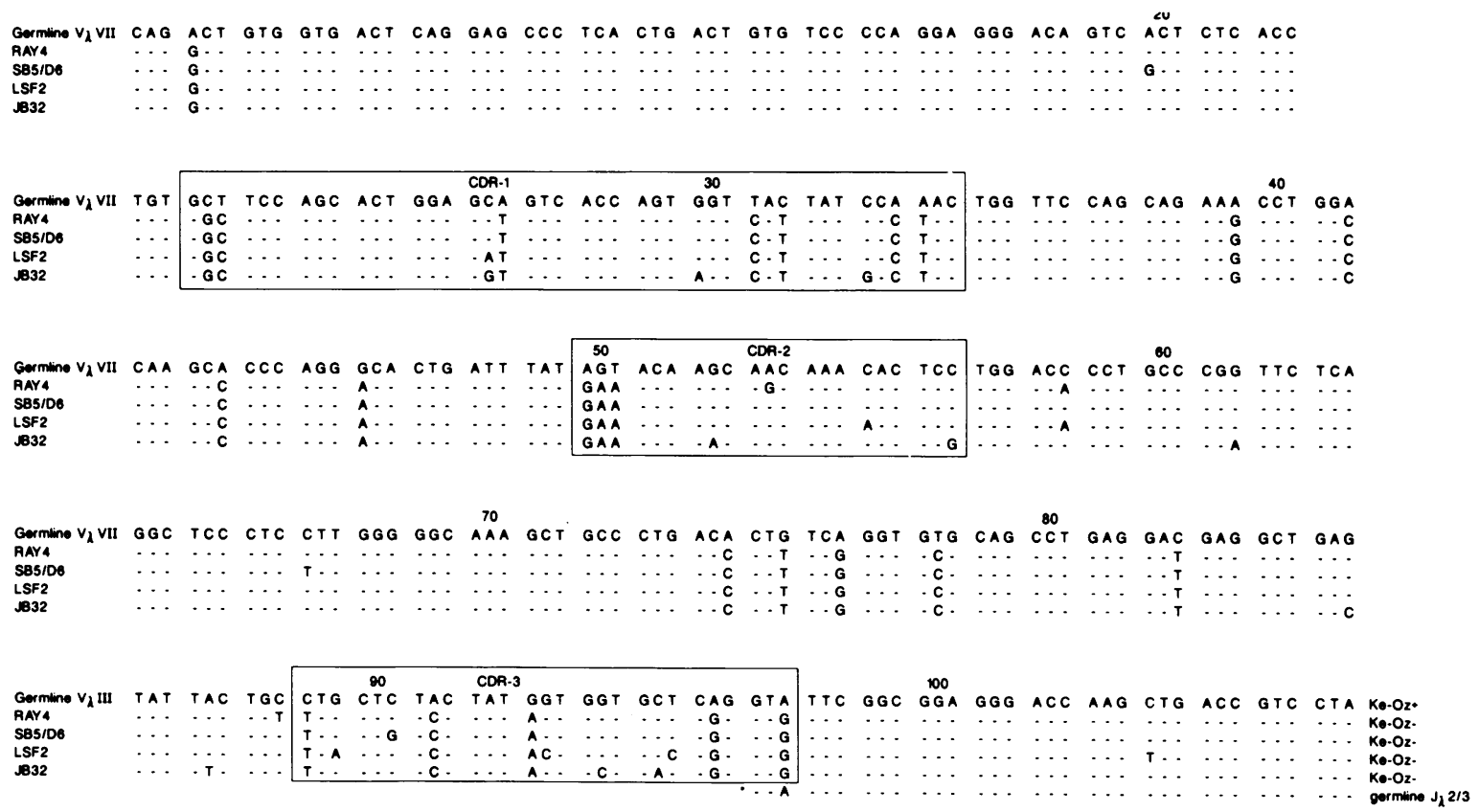

Figure 1. Nucleotide sequences of the $\mathrm{V}_{\lambda}$ and $\mathrm{J}_{\lambda}$ genes from four hybridoma cell lines (RAY4, SB5/D6, LSF2, JB32), and from the $\mathrm{V}_{\lambda} \mathrm{VII}$ germline gene, 4A (33). Numbering is according to Kabat (23). These sequence data are available from EMBL/GenBank Data Libraries under accession numbers M80917 (RAY4), M80918 (SB5/D6), M80915 (LSF2), and M80919 (JB32). 


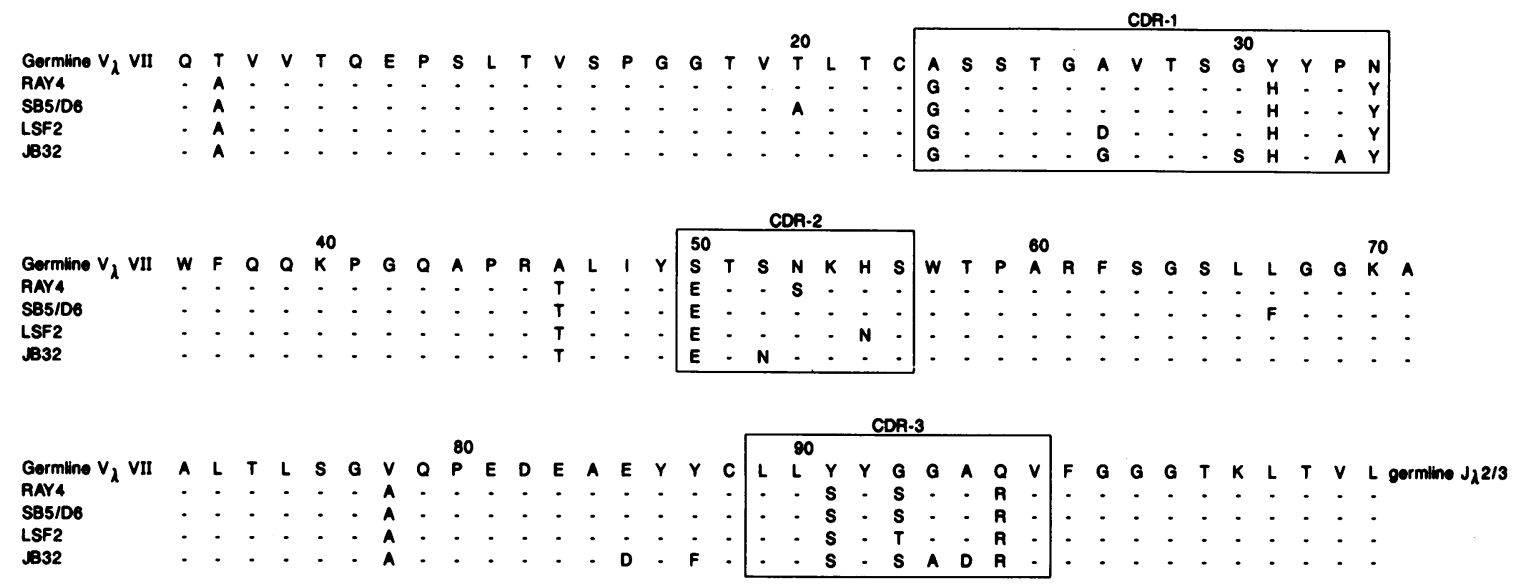

Figure 2. Translated amino acid sequences of $\mathrm{V}_{\lambda}$ and $\mathrm{J}_{\lambda}$ from four hybridoma cell lines (RAY4, SB5/D6, LSF2, JB32), and from the $\mathrm{V}_{\lambda} \mathrm{VII}$ germline gene, 4A (33). (See Fig. 1.)

These two $\mathrm{V}_{\lambda}$ II-encoded gene segments are $91 \%$ homologous to one another, and have in common a number of nucleic acid differences from the $\mathrm{V}_{\lambda} 2.1$ germline gene (especially in CDRs). Whether they derive from another germline gene, or whether these differences reflect mutation, is unknown.

All four of the $V_{\lambda}$ VII-encoded antibodies are also encoded by $\mathrm{V}_{\mathrm{H}}$ III segments closely homologous to the germline gene 9.1 (5). Similar $V_{H}$ segments also encode $A b$ utilizing other $V_{\lambda}$ and $\mathrm{V}_{\kappa}$ gene segments (Table II) (manuscript in preparation). It is uncertain whether pairing of 9.1-like $V_{H}$ and $V_{\lambda}$ VII-encoded heavy and light chains contributes to binding specificity or avidity. JB21 and RC3, also encoded by 9.1-like $V_{H}$ gene segments, but paired with $\mathrm{V}_{\lambda} \mathrm{II}$ - and $\mathrm{V}_{\boldsymbol{\alpha}} \mathrm{II}$-encoded light chains, respectively, do not cross-react with K100 PS.
All six of the lambda light chains are encoded by a common $J_{\lambda}$ segment closely homologous to both $J_{\lambda} 2$ and $J_{\lambda} 3$ germline genes (Fig. 1) (23). $\mathrm{J}_{\lambda} 2$ is associated with the use of the $\left(\mathrm{Kern}^{-} \mathrm{Oz}^{-}\right) \mathrm{C}_{\lambda}$ segment 2 , and $\mathrm{J}_{\lambda} 3$ with the $\left(\mathrm{Kern}^{-} \mathrm{Oz}^{+}\right) \mathrm{C} \lambda$ segment 3 (37). Each of these $J_{\lambda}$ segments substitutes the codon GTG for the reported germline sequence GTA at amino acid position 97. Interestingly, this change does not result in an amino acid replacement, and is therefore not of importance in antigen binding. This minor sequence difference may reflect a shared genetic polymorphism, rather than somatic mutation.

The hybridoma RC3 uses a V $\mathrm{VI}$ segment identical to the germline $\mathrm{V}_{\kappa}$ II gene $\mathrm{A} 2$, and a $\mathrm{J}_{\kappa} 3$ segment closely homologous to the germline sequence (Fig. 5) (13). The second kappa hybridoma, ED6.1, is encoded by a member of the $V_{k} I$ family

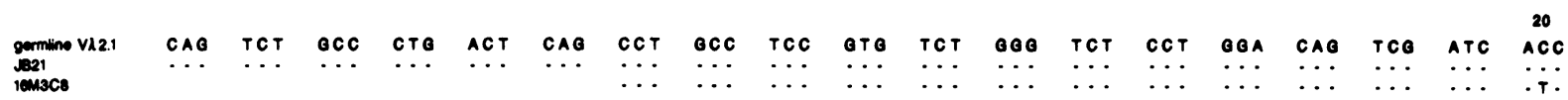

\begin{tabular}{|c|c|c|c|c|c|c|c|c|c|c|c|c|c|c|c|c|c|c|}
\hline \multirow{3}{*}{ 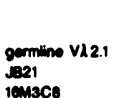 } & \multirow[b]{2}{*}{ ATC } & \multirow[b]{2}{*}{ TCC } & \multirow[b]{2}{*}{ TOC } & \multirow[b]{2}{*}{$\begin{array}{l}A C T \\
\ldots\end{array}$} & \multirow[b]{2}{*}{ OOA } & \multirow[b]{2}{*}{$A C C$} & \multirow[b]{2}{*}{$A B C$} & \multicolumn{3}{|c|}{ CDR-1 } & \multicolumn{4}{|c|}{30} & \multirow[b]{2}{*}{$\begin{array}{l}\text { CTT } \\
\text { TA. }\end{array}$} & \multirow[b]{2}{*}{ OTC } & \multirow[b]{2}{*}{$\begin{array}{l}\text { TCC } \\
\cdots .\end{array}$} & \\
\hline & & & & & & & & $\begin{array}{l}A Q T \\
\cdots\end{array}$ & $\begin{array}{l}\text { OAT } \\
\because C \mathrm{C}\end{array}$ & $\begin{array}{l}\text { OT T } \\
\cdots\end{array}$ & $\begin{array}{l}Q Q B \\
\cdots T\end{array}$ & $\begin{array}{l}A G T \\
\text { GC. }\end{array}$ & $\begin{array}{l}T A T \\
\cdots\end{array}$ & $\hat{A A C}$ & & & & $T B O$ \\
\hline & $\cdots$ & $\cdots$ & . & $0 \cdots$ & $\cdots$ & .6. & $\cdots$ & $\cdots$ & $\cdots$ & $\cdots$ & $\cdots$ & $\cdots$ & $\cdots$ & $\cdots T$ & $\cdots$ & $\cdots$ & $\cdots$ & \\
\hline
\end{tabular}

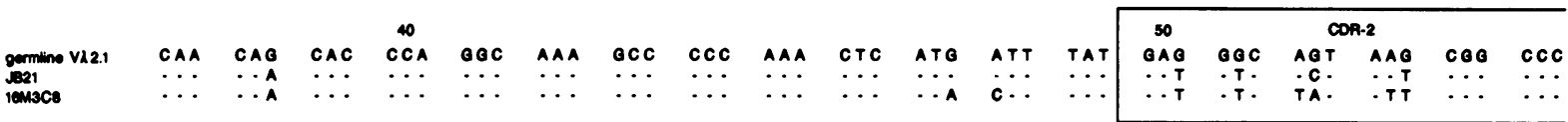

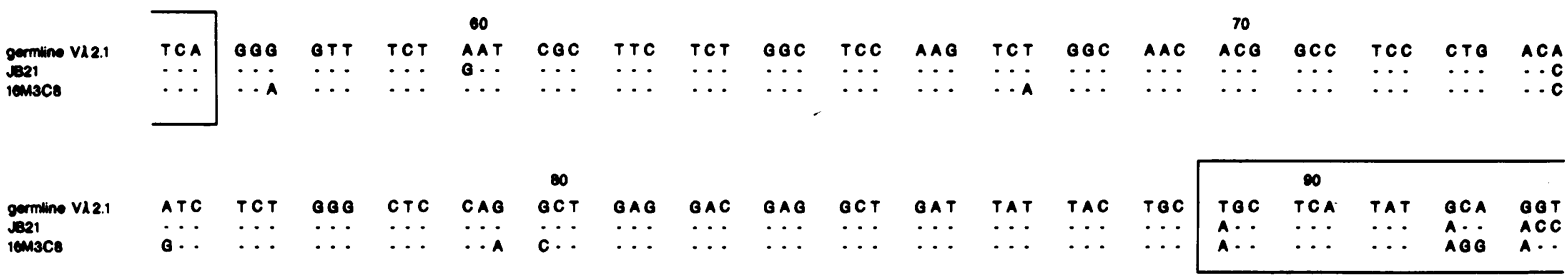

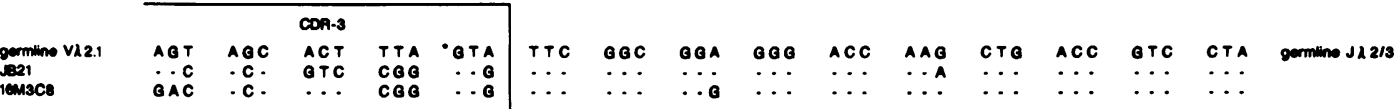

Figure 3. Nucleotide sequences of $\mathrm{V}_{\lambda}$ and $\mathrm{J}_{\lambda}$ genes from two hybridoma cell lines (JB21 and 16M3C8). Also shown is a germline gene V2.1 (34), and germline $J_{\lambda} 2 / 3$ gene (23). An asterisk denotes the beginning of the $J_{\lambda}$ segment. Numbering is according to Kabat (23). These sequence data are available from EMBL/GenBank Data Libraries under accession numbers M80916 (JB21) and M80921 (16M3C8). 


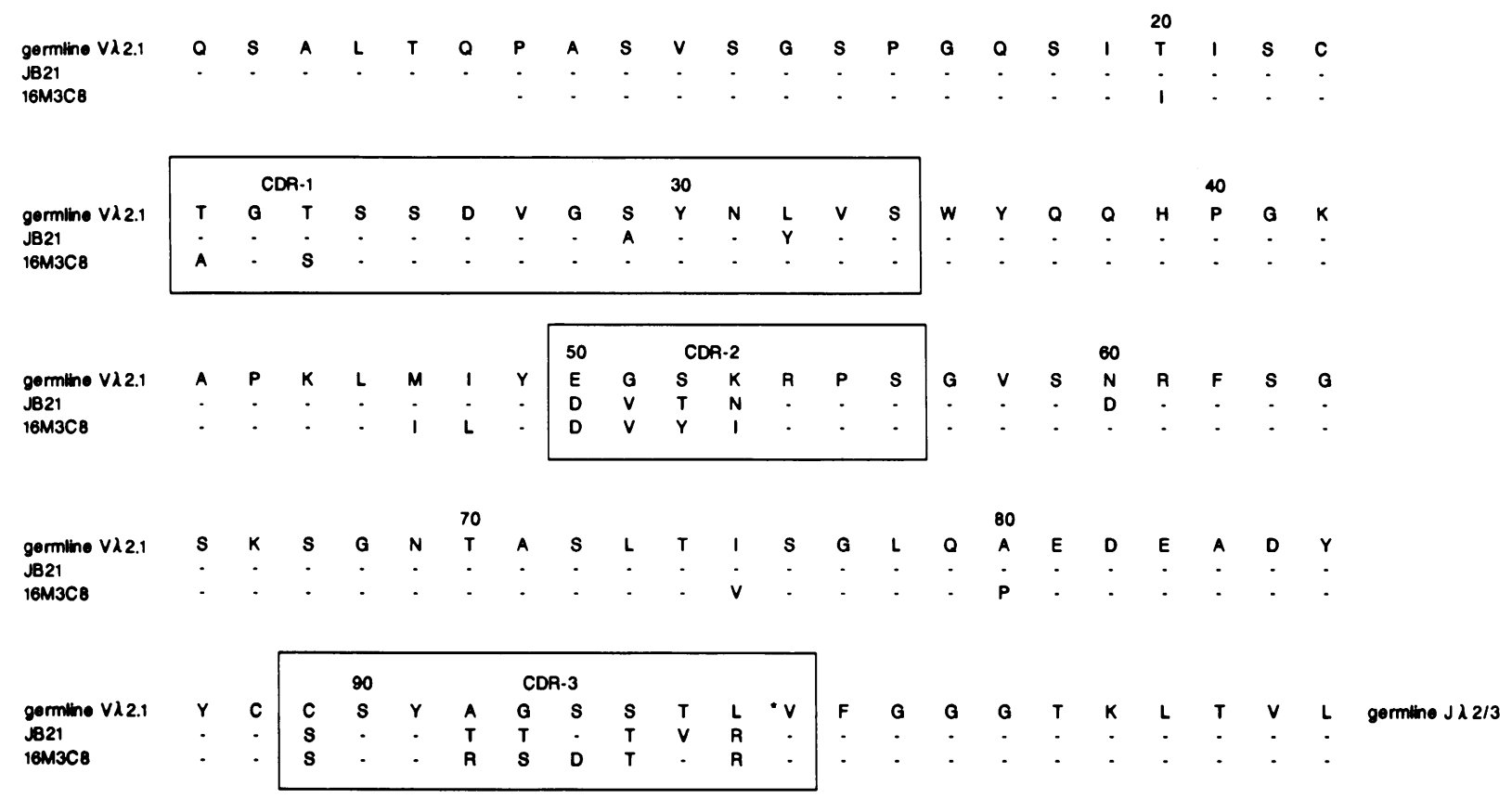

Figure 4. Translated amino acid sequences of $\mathrm{V}_{\lambda}$ and $\mathrm{J}_{\lambda}$ genes from two hybridoma cell lines (JB21 and 16M3C8). Shown for comparison is the translated sequence of the $V_{\lambda}$ germline gene $V_{\lambda} 2.1$, and $J_{\lambda} 2 / 3$ germline gene. An asterisk denotes the beginning of the $J_{\lambda}$ segment. (See Fig. 3.)

(36), and uses a $\mathrm{J}_{\mathrm{k}} 4$ segment differing from the germline sequence by a single base (Fig. 6). The ED6.1 sequence is identical to the partial amino acid sequence reported previously for 2 kappa antibodies purified from serum (12).

$\mathrm{VJ}$ joints of seven of these eight hybridoma $\mathrm{V}_{\mathrm{L}}$ genes are notable for the presence of an arginine codon (Fig. 7). Comparison of germline sequences indicates that in the RC3 $V_{L}$ gene, the codon CGA could only have arisen by the addition of a non-germline-encoded $G$ at the $V_{\alpha} J_{k}$ joint. In the $V_{\lambda} V I I-e n-$ coded antibodies, the relevant germline $V_{\lambda}$ segment is unknown. The arginine codon may be germline-encoded, or result from either mutation or $\mathrm{N}$ sequence addition. The $\mathrm{VJ}$ splice junction in all lambda antibodies is identical, implying this $V_{\lambda} / J_{\lambda}$ combination is a necessary prerequisite for generation of the arginine. Since the CDR-3 region encodes the third hypervariable region, the frequent finding of an arginine residue at this location, and particularly its presence in both kappa

Table II. Summary of $V_{H}$ and $V_{L}$ Gene Segments*

\begin{tabular}{|c|c|c|}
\hline Hybridoma & $V_{H}$ Segment & $V_{L}$ Segment \\
\hline SB5/D6 & $\mathrm{V}_{\mathrm{H}}$ III $9.1(5)$ & $\mathrm{V}_{\lambda}$ VII 4A (33) \\
\hline RAY4 & $\mathrm{V}_{\mathrm{H}}$ III 9.1 & V VII 4A \\
\hline JB32 & $\mathrm{V}_{\mathrm{H}}$ III 9.1 & $\mathrm{~V}_{\lambda}$ VII $4 \mathrm{~A}$ \\
\hline JB21 & $V_{H}$ III 9.1 & $\hat{V_{\lambda}}$ II $2.1(34)$ \\
\hline $\mathrm{RC} 3$ & $\mathrm{~V}_{\mathrm{H}}$ III 9.1 & V II A2 (13) \\
\hline LSF2 & $\mathrm{V}_{\mathrm{H}}$ III 9.1 & $\mathrm{~V}_{\lambda}$ VII $4 \mathrm{~A}$ \\
\hline $16 \mathrm{M} 3 \mathrm{C} 8$ & V $_{\text {HII VH26 (35) }}$ & $\hat{V_{\lambda} I I} 2.1$ \\
\hline ED6.1 & N.K. & $\mathrm{V}_{\alpha} \mathrm{I}$ clone $\mathrm{KC}-1(36)$ \\
\hline
\end{tabular}

* Columns show name of hybridoma cell line and most closely homologous known germline $V_{H}$ and $V_{L}$ segments. Reference for germline shown in parentheses. NK, Not known. and lambda anti-Hib PS Ab clonotypes, implies this residue is of considerable importance in antigen binding.

\section{Southern blots/analysis of germline $V_{\lambda}$ VII genes}

The available repertoire of $V_{\lambda} V I I$ family members was examined by hybridization of human genomic DNA with the $\mathrm{V}_{\lambda} \mathrm{VII}$ probe generated from LSF2. 10 prominent bands, as well as an additional 5 fainter bands, were demonstrated (Fig. 8). Notably, polymorphism such as the presence or absence of a $5.0-\mathrm{kb}$ fragment, and varying intensity of the $3.5-\mathrm{kb}$ fragment, was demonstrated even within this relatively small sample. The human lambda variable region locus is believed to contain about 60 members, of which 10 are members of the $V_{\lambda}$ VII family (33, 38). The five less prominent bands may represent members of other $V_{\lambda}$ families sharing significant homology with the $V_{\lambda} V I I$ family. To determine if the $V_{\lambda}$ VII-encoded antibodies derive from a single germline gene, an oliogonucleotide probe corresponding to conserved $V_{\lambda}$ VII CDR-1 sequence was used to identify a single $3.7-\mathrm{kb}$ genomic DNA fragment. Although more than one $\mathrm{V}$ gene may be present in a single restriction fragment, both the repeated isolation of highly homologous $\mathrm{V}_{\lambda} \mathrm{VII}$ genes, and the single prominant band detected with the oligonucleotide probe, suggests that a single $V_{\lambda}$ gene may be responsible for the generation of lambda anti-Hib PS Ab that cross-reacts with K100 PS (Fig. 9). Less prominant higher molecular weight bands are also present, but hybridize weakly to the oligomer after subtraction of nonspecific background binding by high molecular weight DNA.

\section{Discussion}

To examine the molecular basis of the immune response to $\mathrm{Hib}$ PS, a panel of hybridomas secreting human monoclonal antiHib PS Ab has been developed. Our previous studies showed exclusive use of members of the $\mathrm{V}_{\mathrm{H}} \mathrm{III}$ gene family in this im- 
ED6. 1

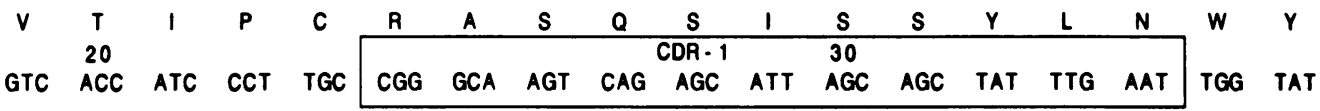

ED6. 1

\begin{tabular}{|c|c|c|c|c|c|c|c|c|c|c|c|c|c|c|c|c|}
\hline H & $K$ & $\mathbf{P}$ & G & $K$ & $A$ & $\mathbf{P}$ & V & L & $\mathbf{L}$ & 1 & L & D & $\mathbf{T}$ & s & $\mathbf{N}$ & $L$ \\
\hline$A C$ & AAA & $\begin{array}{l}40 \\
\text { CCA }\end{array}$ & iGG & AAA & GCC & CCT & GTG & CTC & CTC & ATC & TTA & $\begin{array}{l}50 \\
\text { GAT }\end{array}$ & ACA & TCC & AAT & \\
\hline
\end{tabular}

ED6 . 1

\begin{tabular}{|c|c|c|c|c|c|c|c|c|c|c|c|c|c|c|c|c|c|}
\hline $\mathbf{Q}$ & $\mathbf{s}$ & G & V & $\mathbf{P}$ & s & R & $F$ & s & G & s & G & s & G & $\boldsymbol{T}$ & D & $\mathbf{F}$ & $\mathbf{T}$ \\
\hline CAA & AGT & GGG & GTC & $C C A$ & $\begin{array}{l}60 \\
\text { TCA }\end{array}$ & AGG & TTC & AGT & GGC & AGT & GGA & TCT & GGG & ACA & $\begin{array}{l}70 \\
\text { GAT }\end{array}$ & TTC & ACT \\
\hline
\end{tabular}

ED6. 1

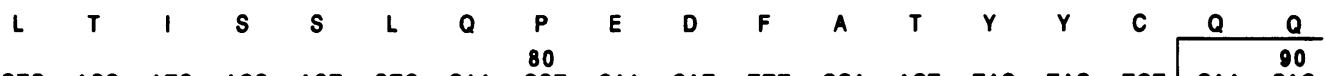
CTC ACC ATC AGC AGT CTG CAA CCT GAA GAT TTT GCA ACt TAC TAC TGT CAA CAG

ED6. 1

\begin{tabular}{|c|c|c|c|c|c|c|c|c|c|c|c|c|c|c|c|c|}
\hline$s$ & $Y$ & $T$ & L & $P$ & L & $T$ & $\mathbf{F}$ & G & G & G & $\mathbf{T}$ & K & $\mathbf{v}$ & E & I & $K$ \\
\hline & & & & & & & & & & & & & & & & \\
\hline G & TAC & ACT & стC & CCG & - CTC & ACT & TTC & GGC & GGA & GGG & ACC & AAG & GTG & GAG & ATC & AAA \\
\hline
\end{tabular}

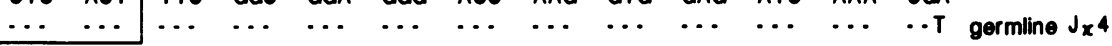

Figure 6. Nucleotide sequence of $\mathrm{V}_{\alpha}$ and $\mathrm{J}_{\kappa}$ genes from hybridoma cell line ED6.1. Also shown is the translated amino acid sequence of the ED6.1 $V_{x}$ gene. An asterisk denotes the beginning of the $J_{\alpha}$ segment. Numbering is according to Kabat (23). This sequence data is available from EMBL/GenBank Data Libraries under accession number M80920 (ED6.1). 


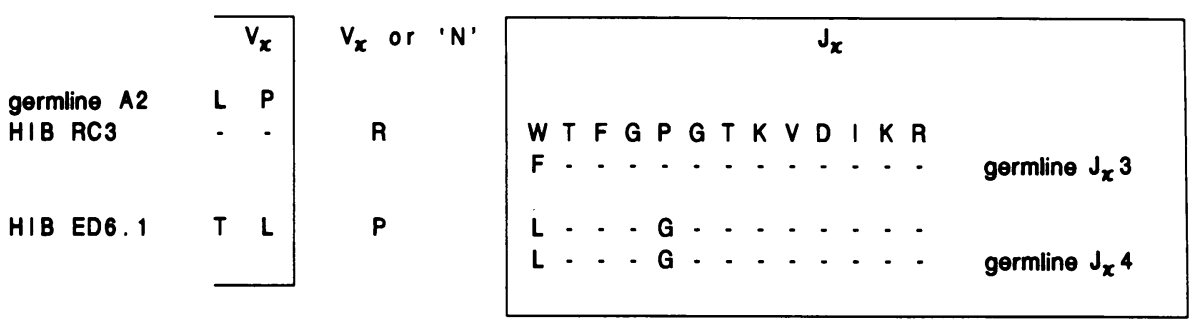

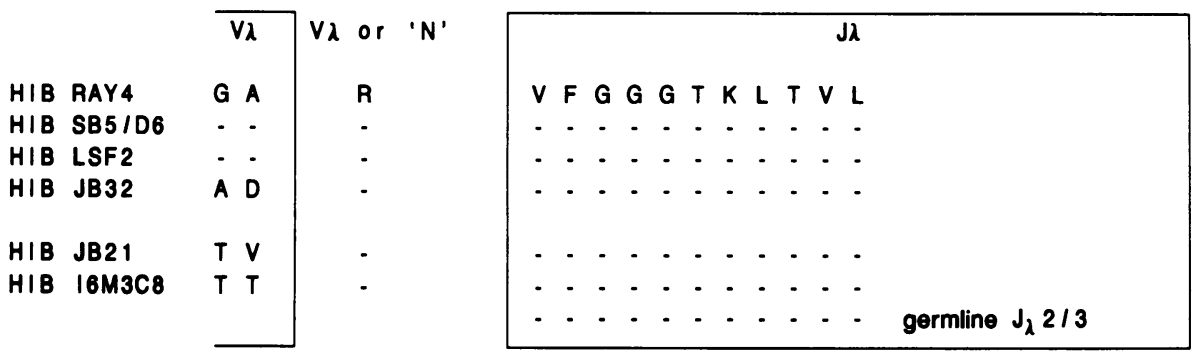

Figure 7. Translated amino acid sequences of $\mathrm{VJ}$ joints from seven hybridoma cell lines (RC3, ED6.1, RAY4, SB5/ D6, LSF2, JB21, and 16M3C8). Also shown are translated amino acid sequences of the germline $V_{k}$ gene $A 2$, and germline $\mathrm{J}_{\kappa} 3, \mathrm{~J}_{\alpha} 4$, and $\mathrm{J}_{\lambda} 2 / 3$ genes. (See Figs. 2, 4, and 6.) mune response, and the apparent restriction to two or three germline $V_{H}$ genes. In contrast, $V_{L}$ gene usage is more complex, with antibody encoded by a number of $V_{\lambda}$ and $V_{k}$ families (12). Analysis of light chain variable region genes obtained from cell lines selected to represent various characteristics of serum antibodies showed that despite diversity in the variety of light chain variable region gene segments utilized, most serum anti-Hib PS Abs may be encoded by a limited number of $V_{k}$ and $V_{\lambda}$ germline genes.

\section{$\begin{array}{llllllllllll}1 & 2 & 3 & 4 & 5 & 6 & 7 & 8 & 9 & 10 & 11 & 12\end{array}$}

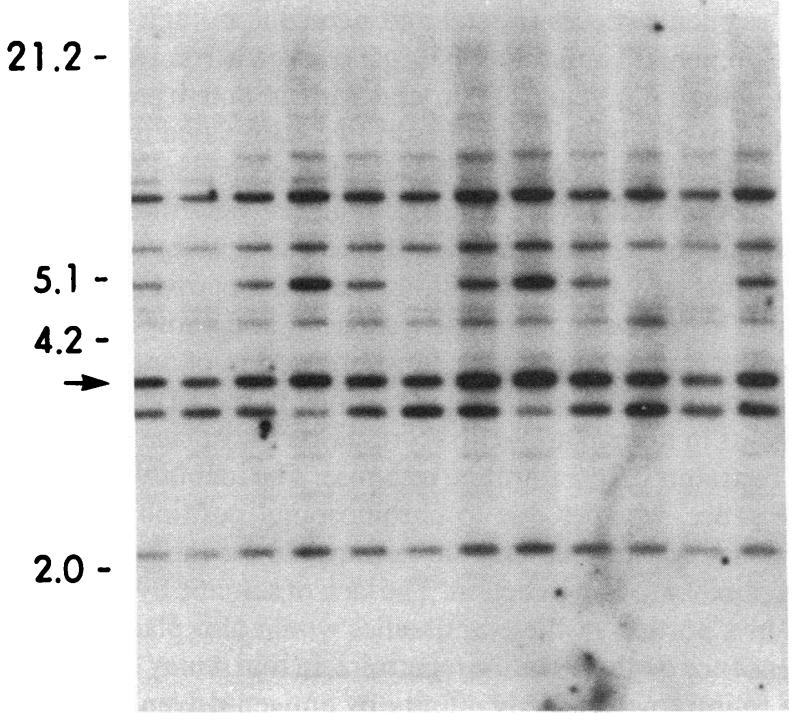

Figure 8. Southern blot analysis for $\mathrm{V}_{\lambda}$ VII family members in BamHI-digested human genomic DNA. Lane 12 contains genomic DNA from the subject from whom hybridoma LSF2 was obtained. Lane 9 contains genomic DNA from a parent of LS. The remaining 10 donors are unrelated. An arrow indicates the $3.7-\mathrm{kb}$ fragment which is identified by the oligonucleotide probe illustrated in Fig. 9.
The light chain distribution of anti-Hib PS Ab is characterized by a predominance of kappa light chains, although some individuals predominantly or exclusively express lambda light chains $(39,40)$. Scott et al. have shown that $\mathrm{V}_{\kappa} \mathrm{II}$ light chains are the most commonly expressed light chains among clonally purified serum anti-Hib PS antibodies from adults with high responses to immunization. Limited amino acid sequences of a number of these serum antibodies showed that greater than $60 \%$ of subjects immunized with plain Hib PS produce antibody encoded by a $\mathrm{V}_{\kappa} \mathrm{II}$ family member, and further, that a number of these antibodies show identical amino acid homology with the translated amino acid sequence of the germline $\mathrm{V}_{\mathrm{k}} \mathrm{I}$ gene $\mathrm{A} 2(12,13)$. Lucas et al. have described an anti-idiotypic monoclonal antibody (Hibid-1) that identifies anti-Hib PS antibodies expressing this light chain (16). On average, $60 \%$

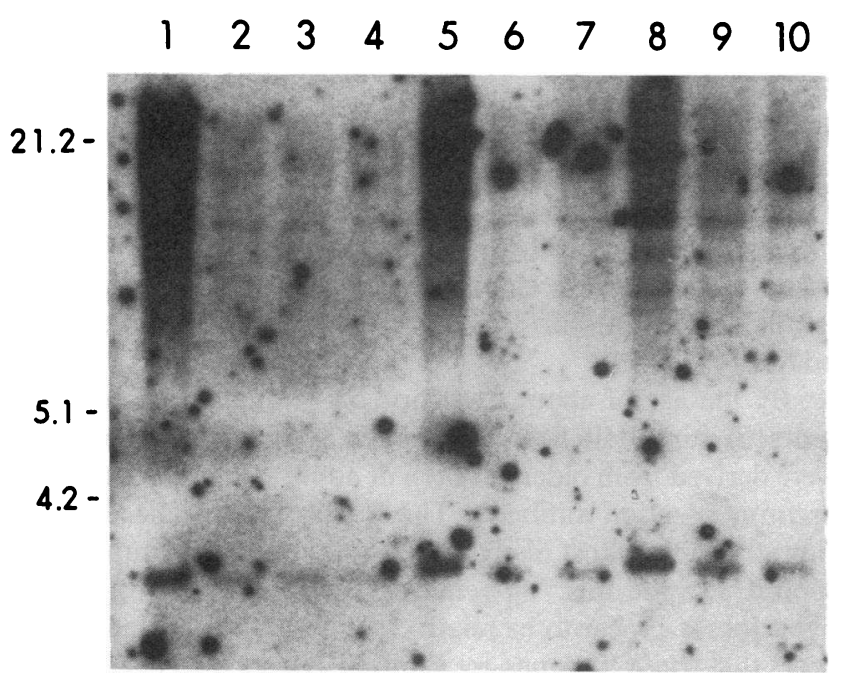

Figure 9. Dried gel hybridization of BamHI-digested human genomic DNA with an oligonucleotide probe corresponding to conserved $\mathrm{V}_{\lambda}$ VII hybridoma CDR-1 sequences. Genomic DNA in lanes $1,4,5$, $6,7,9$ and 10 of Fig. 8 corresponds to that in lanes 2, 7, 4, 8, 10, 5 and 9 of Fig. 9, respectively. 
of the total anti-Hib PS antibody of most children and adults immunized with either Hib PS or Hib PS-conjugate vacine expresses this idiotype $(15,16)$. Taken together, this suggests the most common clonotype of anti-Hib PS Ab is encoded by a single $V_{k}$ II gene. The $V_{k}$ locus contains approximately 50 functional genes, of which $40 \%$ are members of the $V_{\kappa} I I$ family (41). The $V_{k}$ II A2 germline gene is known to be present in a single copy (13). Our findings definitively demonstrate that at least a portion of $\mathrm{V}_{\kappa} \mathrm{II}$-encoded antibodies are encoded by unmutated germline elements. Our subject R.C. was immunized with PS-protein conjugate vaccine, whereas Scott's subjects were immunized with the plain PS vaccine. Thus it is possible that the unmutated $V_{\kappa}$ II A2 segment is utilized irrespective of antigen presentation in a $\mathrm{T}$-independent or $\mathrm{T}$-dependent form.

Lambda variable region gene usage appears similarly restricted. The majority of lambda-expressing anti-Hib PS Ab in adults with high antibody responses to vaccine cross-reacts with $E$. coli K100 PS (17). The capsular polysaccharides of Hib and $E$. coli $\mathrm{K} 100$ are structurally similar and gastrointestinal colonization with $E$. coli $\mathrm{K} 100$ induces antibody to Hib PS in humans (42). "Naturally occurring" anti-Hib PS Ab in children commonly cross-reacts with K100 PS, whereas Ab of individuals immunized with $\mathrm{Hib} \mathrm{PS}$ or responding to $\mathrm{Hib}$ infection is less frequently cross-reactive (18). The kappa/lambda ratio of natural anti-Hib PS Ab is lower in infants than in older children, and in the vaccine-induced antibody of adults (39). Further, Hibid-1 (the CRI associated with expression of the $\mathrm{V}_{\kappa}$ II light chain) is expressed less frequently and comprises a smaller proportion of total anti-Hib PS $\mathrm{Ab}$ in preimmune compared with postimmunization sera. Expression of Hibid-1 following immunization is similar in adults and children. These results imply that cross-reactive antigens may induce the natural antibody of children. K100 PS-cross-reactive antibody may provide protective immunity in young children upon first exposure to Hib. These cross-reactive antibodies appear to be subsequently replaced or dominated by antibody specific for Hib PS when individuals are exposed to this antigen by immunization, colonization, or infection. We demonstrate that cross reactivity of lambda antibodies may be mediated through a single light chain germline gene. The mechanism for the clonal dominance of the $\mathrm{V}_{\kappa} \mathrm{II}$ antibodies is unclear; the avidity for $\mathrm{Hib}$ PS of these K100 PS-cross-reactive antibodies from adults is similar to that of Hib specific PS antibodies (P. Shackelford, unpublished observation).

Lambda antibodies expressing the $\mathrm{V}_{\lambda}$ II gene did not crossreact with $E$. coli $\mathrm{K} 100 \mathrm{PS}$. Whether all noncross-reactive antibodies are encoded by closely related members of the $V_{\lambda}$ II gene family will require further characterization of additional antibodies.

By the age of about 5 yr most individuals have acquired protective anti-Hib PS Ab. All of the hybridomas in this study were derived from older children or adults, who had detectable preimmunization antibody. The B cells immortalized by fusion, therefore, most likely represent a secondary immune response. Despite this, $V_{H}$ gene segments obtained from these hybridomas appear to be relatively unmutated (14), and it appears that some $V_{L}$ genes are similarly conserved. The RC3 $V_{\text {* }}$ gene segment is identical to the A2 germline gene, and although the pertinent $V_{\lambda}$ VII germline gene is not known, the paucity of differences in $V_{\lambda}$ VII segments from four different subjects suggests these gene segments are relatively unmutated. $J_{\kappa}$ and $J_{\lambda}$ segments are also highly homologous to germline ele- ments. Thus, at least a portion of the anti-Hib PS response represents the use of unmutated germline elements.

VJ joints of the majority of rearranged $V_{L}$ genes also appear to be an additional source of restriction in the anti-Hib PS immune response. Although there is variability in the use of $J_{*}$ segments, $V_{\alpha}$ II-encoded $V_{L}$ genes are characterized by the presence of an arginine at amino acid position 95a (13). In the RC3 $\mathrm{V}_{\mathrm{L}}$ gene and at least one of the antibodies (B-G2a) described by Scott, this appears to have arisen by $\mathrm{N}$ sequence addition. In four other kappa antibodies described by Scott, alternative joining may have generated this invariant arginine (13). All of the lambda $V_{L}$ genes in the present study are similarly characterized by an invariant arginine- 96 . The germline $V_{\lambda}$ VII segment is not known; therefore the mechanism used to generate this codon is uncertain. The invariant presence of this residue in many anti-Hib PS Abs supports the previous suggestion that it may be of great importance in antigen binding (13). This also is supported by studies of the murine anti- $p$-azophenylarsonate (Ars) response. Anti-Ars light chains also contain an invariant arginine at position 96 , encoded by intracodonic splicing of a single $V_{k}\left(V_{k} 10\right.$-Ars) and a single $J_{k}\left(J_{k} 1\right)$ segment $(43)$. This arginine is essential for Ars binding, and the substitution of tyrosine for arginine has been shown to abolish binding (44). The presence of arginine residues clustered within the CDR's of the heavy chains of murine anti-DNA antibodies correlates with increased affinity, and the arginine requirement in the anti-Hib PS response may indicate its participation in the recognition of the similar phosphate-ester linkage of the repeating carbohydrate moiety (45). Thus, although diversity exists in the use of a variety of $\mathrm{V}$ and $\mathrm{J}$ segments, certain $\mathrm{VJ}$ combinations, which produce arginine codons by junctional flexibility or $\mathbf{N}$ segment addition, may be strongly selected.

Does the restricted nature of $V_{H}$ and $V_{L}$ segment usage in the human anti-Hib PS response explain the age-related acquisition of immunity to this organism? In both mice and humans, preferential use of certain $V_{H}$ gene segments is observed in early development. In mice, biased usage of $J_{H^{-}}$-proximal $V_{H}$ gene segments occurs in fetal and neonatal animals $(46,47)$. Developmental regulation of $V_{L}$ gene usage is less extensively studied than $\mathrm{V}_{\mathbf{H}}$ genes. Teale and Morris noted preferential expression of certain $V_{k}$ families in LPS-stimulated murine fetal B cells compared to adult B cells, with no evidence for position-dependent bias (48). Kaushik et al. also described nonstochastic use of $V_{k}$ families in adult mice, suggesting molecular constraints may persist beyond the neonatal period (49). Two or three $V_{H}$ gene segments, and a single $V_{k}$ and a single $V_{\lambda}$ gene segments, appear to encode a large proportion of anti-Hib PS $\mathrm{Ab}$ in immune subjects. The use of highly conserved $\mathrm{V}$ gene segments in human anti-Hib PS response may place considerable restraints on the immune response. The inability to utilize these genes, whether due to chromosomal position or other molecular constraints, may be responsible for the age-related susceptibility to Hib infection. The lack of somatic hypermutation in a portion of these antibodies would also place greater dependence on the germline repertoire, in that it may be impossible to improve antibody affinity by antigen-driven selection of favorable mutations. The absence or polymorphism of these genes also may contribute to individual and ethnic susceptibility to invasive $\mathrm{Hib}$ disease. In addition, the repertoire differences detected in some individuals (such as the absence of kappa antibody, or the absence of the $\mathrm{V}_{\kappa} \mathrm{II}$-associated CRI) may be explained by the use of other minor light chains. An individ- 
ual missing the $\mathrm{A} 2$ germline gene has been described, although the functional implications of such a deletion are not known (13).

Expression of certain $\mathrm{V}_{\mathrm{H}}$ gene family members in mice is correlated with $B$ cell subpopulations (50). An alternative explanation for the poor response to plain Hib PS may be a maturational delay in recruitment of a critical B cell population that selectively expresses important variable region gene segments. We and others note that an arginine is expressed at the $\mathrm{VJ}$ joint in the great majority of anti-Hib PS light chains. In some circumstances $\mathbf{N}$ segment addition is required to generate this codon. The addition of these extra nucleotides is infrequent in light chain recombination, suggesting that these B cell precursors may be relatively infrequent (51). Moreover, $\mathrm{N}$ segment addition also appears to be developmentally regulated. Neonatal murine $B$ cells lack $\mathrm{N}$ sequences, and their presence in heavy chain recombination increases with time (52). In addition, $\mathrm{N}$ sequence addition may also correlate with certain $\mathrm{B}$ cell subsets. N segments appear to be rare in Ly1-B cell-derived populations (53).

In contrast to plain polysaccharide vaccines, most young infants respond well to the newer Hib-PS protein conjugate vaccines (54). It is presently unknown if this antigen formulation recruits an alternative antibody repertoire, or if, by an uncertain mechanism, developmental restriction of a "dormant" B cell subset is overcome. To address this question, $\mathrm{V}$ gene expression in infants must be examined.

\section{Acknowledgments}

The authors thank Drs. Moon H. Nahm, Dan M. Granoff, Alan L. Schwartz, and Harvey R. Colten for helpful discussion and review of this manuscript, and Mrs. Darlene Bradley for preparation of the manuscript.

This work was supported by the Lattner Foundation, the Allison Hope Hollenbeck Fund, grant 61 from the March of Dimes, the Markey Center in Molecular Biology of Human Diseases at Washington University, grant R01 A1 19350 and AI17217 from the National Institutes of Allergy and Infectious Diseases, grant RR-36 from the General Clinical Research Center, National Institutes of Health, and a Pediatric Fellowship Award (E. E. Adderson) from Connaught Laboratories, Inc.

\section{References}

1. Tonegawa, S. 1983. Somatic generation of antibody diversity. Science (Wash. DC). 302:575-581.

2. Akira, S., K. Okazaki, and H. Sakano. 1987. Two pairs of recombination signals are sufficient to cause immunoglobulin V-(D)-J joining. Science (Wash. DC). 238:1134-1138.

3. Alt, F. W., T. K. Blackwell, and C. D. Yancopoulos. 1987. Development of the primary antibody repertoire. Science (Wash. DC). 298:1079-1087.

4. French, D. L., R. Laskov, and M. D. Scharff. 1989. The role of somatic hypermutation in the generation of antibody diversity. Science (Wash. DC). 244:1152-1157.

5. Berman, J. E., S. J. Mellis, R. Pollock, C. L. Smith, H. Suh, B. Heinke, C. Kowal, U. Surti, L. Chess, C. R. Cantor, et al. 1988. Content and organization of the human $\mathrm{IgV}_{\mathrm{H}}$ locus: definition of three new $\mathrm{V}_{\mathrm{H}}$ families and linkage to the $\mathrm{IgC}_{\mathrm{H}}$ locus. EMBO (Eur. Mol. Biol. Organ.) J. 7:727-738.

6. Krawinkel, V., T. Christoph, and T. Blankenstein. 1989. Organization of the Ig $\mathrm{V}_{\mathbf{H}}$ locus in mice and humans. Immunol. Today. 10:339-344.

7. Straubinger, B., E. Huber, W. Lorenz, E. Osterholzer, W. Pargent, M. Pech, H.-D. Pohlenz, F.-J. Zimmer, and H. G. Zachau. 1988. The human V locuscharacterization of a duplicated region encoding 28 different immunoglobulin genes. J. Mol. Biol. 199:23-34.

8. Robbins, J. B., J. C. Parke, Jr., R. Schneerson, and J. K. Whisnant. 1973 Quantitative measurement of "natural" and immunization-induced Haemophilus influenzae type b capsular antibodies. Pediatr. Res. 7:103-110.
9. Ward, J. J., H. S. Margolis, M. K. Lum, D. W. Fraser, and T. R. Bender. 1981. Haemophilus influenzae disease in Alaskan Eskimos: Characteristics of a population with an unusual incidence of invasive disease. Lancet. 1:1281-1285.

10. Coulehan, J. L., R. H. Michaels, C. Hallowell, R. Schults, T. K. Welty, and J. S. C. Kuo. 1984. Epidemiology of Haemophilus influenzae type b disease among Navajo Indians. Public Health Rep. 99:404-409.

11. Granoff, D. M., P. G. Shackelford, B. K. Suarez, M. H. Nahm, K. L. Cates, T. V. Murphy, R. Karasic, M. T. Osterholm, J. P. Pandey, and R. S. Daum. 1986. Haemophilus influenzae type b disease in children vaccinated with type b polysaccharide vaccine. N. Engl. J. Med. 315:1584-1590.

12. Scott, M. G., J. J. Tarrand, D. L. Crimmins, D. W. McCourt, N. R. Siegel, C. E. Smith, and M. H. Nahm. 1989. Clonal characterization of the human IgG antibody repertoire to Haemophilus influenzae type b polysaccharide. II. IgG antibodies contain $V_{H}$ genes from a single $V_{H}$ family and $V_{L}$ genes from at least four $\mathrm{V}_{\mathrm{L}}$ families. J. Immunol. 143:293-298.

13. Scott, M. G., D. L. Crimmins, D. W. McCourt, I. Zocher, R. Thiebe, H. G. Zachau, and M. H. Nahm. 1989. Clonal characterization of the human IgG antibody repertoire to Haemophilus influenzae type b polysaccharide. III. A single $\mathrm{V}_{\mathrm{k}}$ II gene and one of several $\mathrm{J}_{\mathrm{K}}$ genes are joined by an invariant arginine to form the most common L chain $V$ region. J. Immunol. 143:4110-4116.

14. Adderson, E. E., P. G. Shackelford, A. Quinn, and W. L. Carroll. 1991. Restricted immunoglobulin heavy chain $\mathrm{V}$ gene usage in the human antibody response to Haemophilus influenzae type b capsular polysaccharide. J. Immunol. 147:1667-1674.

15. Lucas, A. H., and D. M. Granoff. 1990. A major cross-reactive idiotype associated with human antibodies to the Haemophilus influenzae type b capsular polysaccharide. J. Clin. Invest. 85:1158-1166.

16. Lucas, A. H., R. J. Langley, D. M. Granoff, M. H. Nahm, M. Y. Kitamura, and M. G. Scott. An idiotypic marker associated with the germ-line encoded kappa light chain variable region that predominates the vaccine-induced human antibody response to the Haemophilus influenzae b polysaccharide. $J$. Clin. Invest. 88:1811-1818.

17. Tarrand, J. J., M. G. Scott, P. A. Takes, and M. H. Nahm. 1989. Clonal characterization of the human IgG antibody repertoire to Haemophilus influenzae type b polysaccharide. J. Immunol. 142:2519-2526.

18. Insel, R. A., and P. W. Anderson. 1982. Cross-reactivity with Escherichia coli $\mathrm{K} 100$ in the human serum anticapsular antibody response to Haemophilus influenzae type b. J. Immunol. 128:1267-1270.

19. Granoff, D. M., P. G. Shackelford, J. P. Pandey, and E. G. Boies. 1986. Antibody responses to Haemophilus influenzae type b polysaccharide vaccine in relation to the $\mathrm{Km}(1)$ and $\mathrm{G} 2 \mathrm{~m}(23)$ immunoglobulin allotypes. J. Infect. Dis. 154:257-264.

20. Shackelford, P. G., D. M. Granoff, S. J. Nelson, M. G. Scott, D. S. Smith, and M. H. Nahm. 1987. Subclass distribution of human antibodies to Haemophilus influenzae type b capsular polysaccharide. J. Immunol. 138:587-592.

21. Gigliotti, F., L. Smith, and R. A. Insel. 1984. Reproducible production of protective monoclonal antibodies by fusion of peripheral blood lymphocytes with a mouse myeloma cell line. J. Infect. Dis. 149:43-47.

22. Chirgwin, J. M., A. K. Przybyla, R. J. MacDonald, and W. J. Rutter. 1979. Isolation of biologically active ribonucleic acid and from sources enriched in ribonuclease. Biochemistry. 18:5294-5299.

23. Kabat, E. A., T. T. Wu, M. Reid-Miller, H. M. Perry, and K. S. Gottesman. 1987. Sequence of Proteins of Immunological Interest. U.S. Public Health Service, Bethesda, MD.

24. Saiki, R. K., D. H. Gelfand, S. Stoffel, S. J. Scharf, R. Higuchi, G. T. Horn, K. B. Mullis, and H. A. Erlich. 1988. Primer directed enzymatic amplification of DNA with a thermostable DNA polymerase. Science (Wash. DC). 239:487-491.

25. Larrick, J. W., L. Danielsson, C. A. Brenner, E. F. Wallace, M. Abrahamson, K. E. Fry, and C. A. K. Borrebaeck. 1989. Polymerase chain reaction using mixed primers: cloning of human monoclonal antibody variable region genes from single hybridoma cells. Biotechnology. 7:934-938.

26. Sanger, F., S. Nicklen, and A. R. Coulson. 1977. DNA sequencing with chain-terminating inhibitors. Proc. Natl. Acad. Sci. USA. 79:5463-5467.

27. Davis, L. G., M. D. Dibner, and J. F. Battey. 1986. Preparation of DNA from eukaryotic cells: General method. In Basic Methods of Molecular Biology. L. G. Davis, M. D. Dibner, and J. F. Battey, editors. Elsevier, New York. 44-46.

28. Feinberg, A. P., and B. Vogelstein. 1983. Technique for radiolabelling DNA restriction endonuclease fragments to high specific activity. Anal. Biochem. 132:6-13.

29. Hellman, L., and V. Petterson. 1987. Analysis of closely related genes by the use of synthetic oligonucleotide probes labelled to a high specific activity. Gene Anal. Tech. 4:9-13.

30. Tsao, S. G., C. F. Brunk, and R. E. Pearlman. 1983. Hybridization of nucleic acids directly in agarose gels. Anal. Biochem. 131:365-372.

31. Miyada, C. G., C. Klofelt, A. A. Reyes, E. McLaughlin-Taylor, and R. B. Wallace. 1985. Evidence that polymorphism in the murine major histocompatibility complex may be generated by an assortment of subgene sequences. Proc. Natl. Acad. Sci. USA 82:2890-2894.

32. Devereux, J., P. Haeberli, and O. Smithies. 1984. A comprehensive set of sequence analysis programs for the Vax. Nucleic Acids Res. 12:387-395. 
33. Anderson, M. L. M., M. F. Szajnert, J. C. Kaplan, L. McColl, and B. D. Young. 1984. The isolation of a human Ig $V_{\lambda}$ gene from a recombinant library of chromosone 22 and estimation of the copy number. Nucleic Acids Res. 12:66476660 .

34. Brockley, F., D. Alexandre, P. Chuchana, S. Huck, G. Lefranc, and M.-P. Lefranc. 1989. First nucleotide sequence of a human immunoglobulin variable $\lambda$ gene belonging to subgroup II. Nucleic Acids Res. 10:3976.

35. Chen, P. P., M., Liu, S., Sinha, and D. A. Carson. 1988. A 16/6 idiotypepositive anti-DNA antibody is encoded by a conserved $V_{H}$ gene with no somatic mutation. Arthritis Rheum. 31:1429-1431.

36. Kato, S., K. Tachibana, N. Takayama, H. Kataoka, M. Yoshida, and T. Takano. 1991. Genetic recombination in chromosomal translation $\mathrm{t}(2 ; 8)(\mathrm{pl1} ; \mathrm{q} 24)$ of a Burkitt's lymphoma cell line, KOBK101. Gene (Amst.). 97:239-244.

37. Udey, J., and B. Blomberg. 1987. Human $\lambda$ light chain locus: Organization and DNA sequences of three genomic $J$ regions. Immunogenetics. 25:63-70.

38. Chuchana, P., A. Blancher, F. Brockly, D. Alexandre, G. Lefranc, and M.-P. Lefranc. 1990. Definition of the human immunoglobulin variable lambda (IGLV) gene subgroups. Eur. J. Immunol. 20:1317-1325.

39. Ambrosino, D. M., W. Greif, C. Thompson, and G. R. Siber. 1990. $\kappa$ and $\lambda$ light chain composition of antibody to the capsular polysaccharide of Haemophilus influenzae type b. J. Infect. Dis. 161:922-925.

40. Insel, R. A., P. Anderson, M. E. Pichichero, S. Schuster, M. D. Amster, G. Ekborg, and D. H. Smith. Anticapsular antibody to Haemophilus influenzae. In Haemophilus Influenzae. S. H. Sell and P. F. Wright, editors. Elsevier, New York. 115-168.

41. Meindl, A., H. G. Klobeck, R. Ohnheiser, and H. G. Zachau. 1990. The $\mathrm{V}_{\mathrm{K}}$ gene repertoire in the human germ line. Eur. J. Immunol. 20:1855-1863.

42. Schneerson, R., and J. B. Robbins. 1975. Induction of serum Haemophilus influenzae type $\mathrm{b}$ capsular antibodies in adult volunteers fed cross-reacting Escherichia coli 075:K100:H5. N. Engl. J. Med. 292:1093-1096.

43. Sanz, I., and J. D. Capra. 1987. $V_{k}$ and $J_{k}$ gene segments of A/J Ars-A antibodies: Somatic recombination generates the essential arginine at the junc- tion of the variable and joining regions. Proc. Natl. Acad. Sci. USA 84:10851089.

44. Jeske, D. J., J. Jarvis, C. Milstein, and J. D. Capra. 1984. Junctional diversity is essential to antibody activity. J. Immunol. 133:1090-1092.

45. Shlomchik, M., M. Mascelli, H. Shan, M. Z. Radic, D. Pisetsky, A. Marshak-Rothstein, and M. Weigert. 1990. Anti-DNA antibodies from autoimmune mice arise by clonal expansion and somatic mutation. J. Exp. Med. 171:265-297.

46. Yancopoulos, G. D., S. V. Desiderio, M. Paskind, J. F. Kearney, D. Baltimore, and F. W. Alt. 1984. Preferential utilization of the most JH-proximal $V_{\mathrm{H}}$ gene segments in pre-B-cell lines. Nature (Lond.). 311:727-733.

47. Perlmutter, R. M., J. F. Kearney, S. P. Chang, and L. E. Hood. 1985. Developmentally controlled expression of immunoglobulin $\mathrm{V}_{\mathrm{H}}$ genes. Science (Wash. DC). 227:1597-1601.

48. Teale, J. M., and E. G. Morris. 1989. Comparison of $V_{\text {, gene family }}$ expression in adult and fetal B cells. J. Immunol. 143:2768-2772.

49. Kaushik, A., D. H. Schulze, C. Bona, and G. Kelsoe. 1989. Murine $V_{k}$ gene expression does not follow the $\mathrm{V}_{\mathrm{H}}$ paradigm. J. Exp. Med. 169:1859-1864.

50. Jeong, H. D., and J. M. Teale. 1990. Contribution of the $\mathrm{CDS}^{+} \mathrm{B}$ cell to D-proximal $V_{H}$ family expression early in ontogeny. J. Immunol. 145:27252729.

51. Carroll, W. L., C. O. Starnes, R. Levy, and S. Levy. 1988. Alternative V, gene rearrangements in a murine B cell lymphoma. An explanation for idiotypic heterogeneity. J. Exp. Med. 168:1607-1620.

52. Feeney, A. J. 1990. Lack of $\mathrm{N}$ regions in fetal and neonatal mouse immunoglobulin V-D-J junctional sequences. J. Exp. Med. 172:1377-1390.

53. Gu, H., I. Forster, and K. Rajewsky. 1990. Sequence homologies, N sequence insertion and $J_{H}$ gene utilization in $V_{H} D J_{H}$ joining: implications for the joining mechanism and the ontogenic timing of Ly1 B cell and B-CLL progenitor generation. EMBO (Eur. Mol. Biol. Organ.) J. 9:2133-2140.

54. Eskola, J., H. Kayhty, H. Peltola, V. Karanko, P. H. Makela, J. Samuelson, and L. K. Gordon. 1985. Antibody levels achieved in infants by course of Haemophilus infleunzae type b polysaccharide/diphtheria toxoid conjugate vaccine. Lancet. 1:1184-1186. 